FRG PROJECT

5. Proj./Prog./Dept./Div.:

FRG PROJECT (C-229)

8. Originator Remarks:

PMP for FRG Project.

3. From: (Originating organization) FRG PROJECT

6. Design Authority/ Design Agent/Cog. Engr.:

I. L. Metcalf
2. To: (Receiving Organization)

T No.:

$\mathrm{N} / \mathrm{A}$

7. Purchase Order No.:

$N / A$

9. Equip./Component No.:

N/A

10. System/Bldg./Facility: 324 Building

11. Receiver Remarks: 11A. Design Baseline Document? [] Yes [X] No
12. Major Assm. Dwg. No.:

N/A

13. Permit/Permit Application No.: $\mathrm{N} / \mathrm{A}$

14. Required Response Date:

N/A

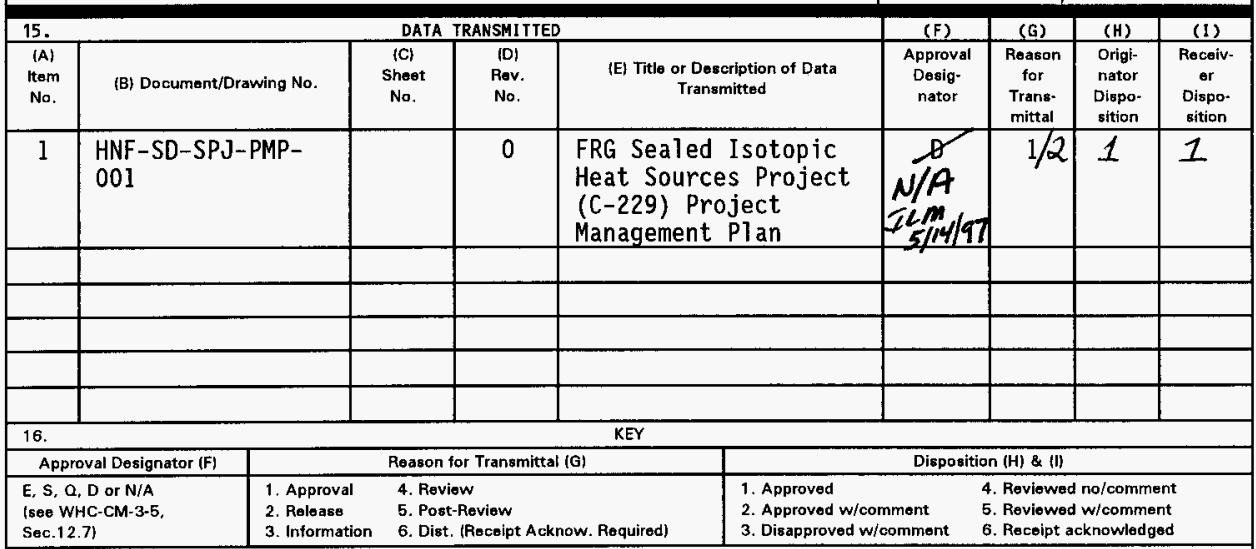

17. SIGNATURE/DISTRIBUTION

(See Approval Designator for required signatures)

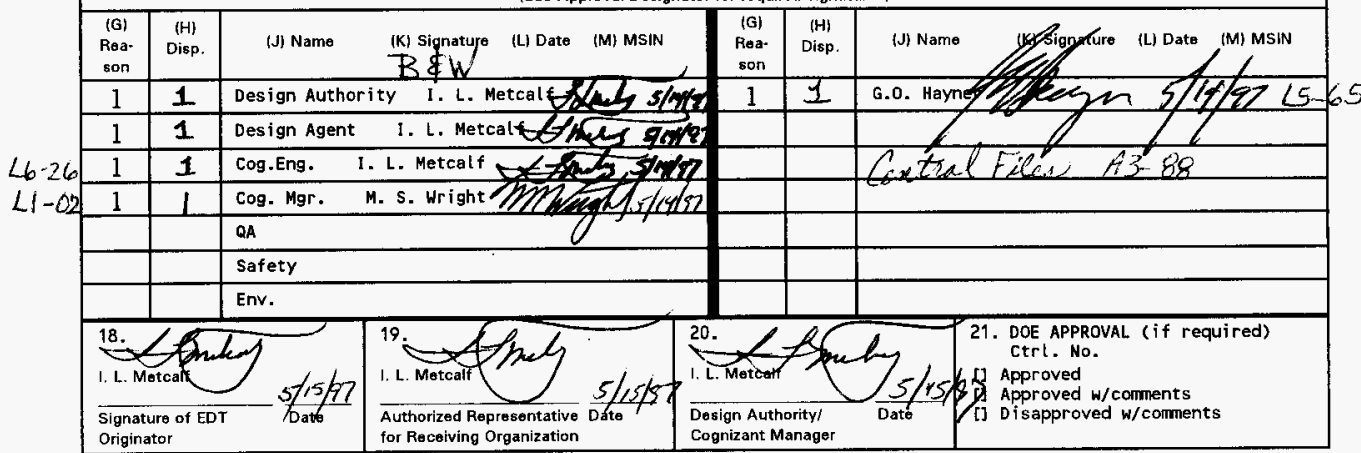

BD-7400-172-2 (05/96) GEF097 


\section{FRG Sealed Isotopic Heat Sources Project (C-229) Project Management Plan}

I. L. Metcalf

B\&W Hanford Company, Richland, WA 99352

U.S. Department of Energy Contract DE-AC06-96RL13200

$\begin{array}{lll}\text { EDT/ECN: } & 606218 & \text { UC: } 2050 \\ \text { Org Code: } & 19120 & \text { Charge Code: K4lAl } \\ \text { B\&R Code: } & 600302000 & \text { Total Pages: } 54\end{array}$

Key Words: FRG, Project Management Plan, 324 Building, CWC, Isotopic Heat Source

Abstract: This Project Management Plan defines the cost, scope, schedule, organizational responsibilities, and work breakdown structure for the removal of the Federal Republic of Germany (FRG) Sealed Isotopic Heat Sources from the 324 Building and placed in interim storage at the Central Waste Complex (CWC).

IRADEMARK DISCLAIMER. Reference herein to any specific comercial product, process, or service by trade name, trademark, manufacturer, or otherwise, does not necessarily constitute or imply its endorsement, recommendation, or favoring by the United States Government or any agency thereof or its contractors or subcontractors.

Printed in the United States of America. To obtain copies of this document, contact: WHC/BCS Document Control Services, P.O. Box 1970, Mailstop H6-08, Fax $(509) \quad 376-4989$.
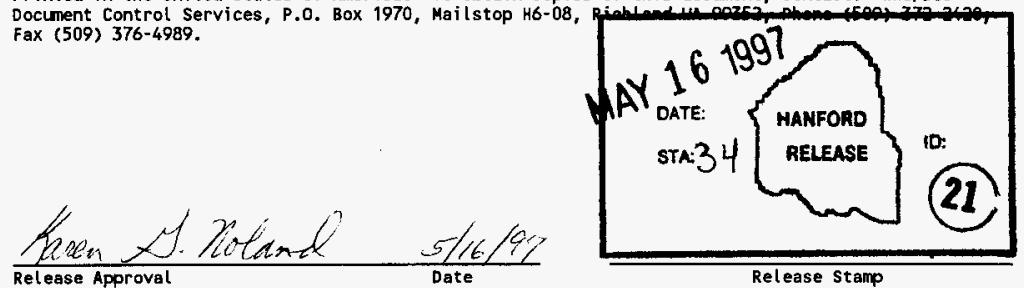

Release Stamp 
HNF-SD-SPJ-PMP-001

Rev. 0

\section{TABLE OF CONTENTS}

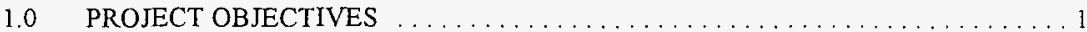

1.1 Purpose . . . . . . . . . . . . . . . . . . . . . . . . . 1

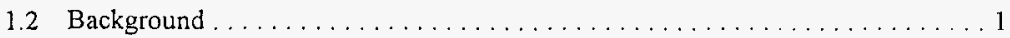

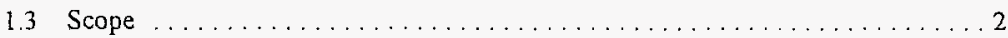

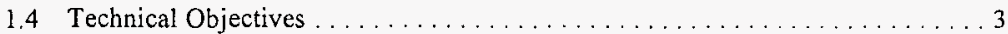

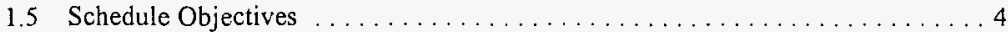

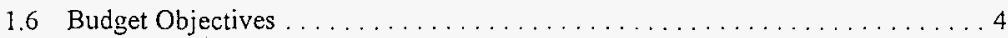

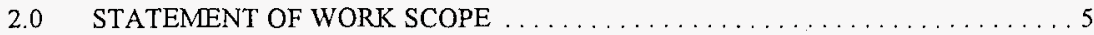

2.1 Project Objectives ................................ 5

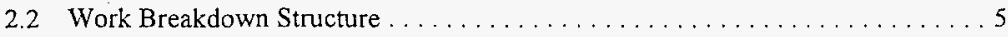

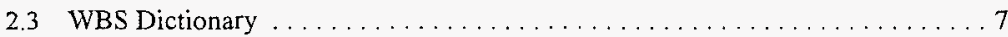

2.3.1 Project Management (WBS No. 1.00) .................. 7

2.3.1.1 Project Management (WBS No. 1.10) ............ 7

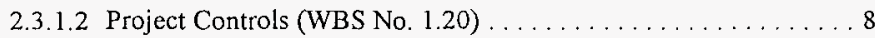

2.3.1.3 NEPA/Site Permits (WBS No 1.30$) \ldots \ldots \ldots \ldots \ldots \ldots \ldots$

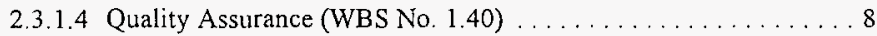

2.3.1.5 Readiness Determination (WBS No. 1.50) ........... 9

2.3.1.6 Path Forward (WBS No. 2.00) . . . . . . . . . . . . . . . 9

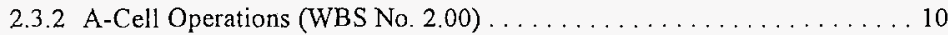

2.3.2.1 A-Cell Pre-Transfer Preparation (WBS No. 2.10) ........ 10

2.3.2.2 324 Building Loadout Activities (WBS No. 2.20) . . . . . . 10

2.3.2.3 Post-Transfer Decontamination and Decommissioning

(WBS No. 2.30) . . . . . . . . . . . . . . . . . 11

2.3 .3 Cask/Transportation (WBS No. 3.00) ................... 11

2.3.3.1 Shipping/Storage Cask Acquisition (WBS No. 3.10) ...... 11

2.3.3.2 SARP(s) Preparation (WBS No. 3.20) . . . . . . . . . . 12

2.3.3.3 Transfer Operations (WBS No. 3.30) ............... 12 
HNF-SD-SPJ-PMP-001

Rev. 0

\section{TABLE OF CONTENTS (CONTINUED)}

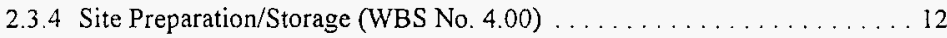

2.3.4.1 Consequence Analysis/Vulnerability Assessment

(WBS No. 4.10) ........................ 13

2.3.4.2 Solid Waste SAR Modifications and USQ Disposition

(WBS No. 4.20) ........................ 13

2.3.4.3 Site Selection/Functional Design Criteria (WBS No. 4.30) . . . 13

2.3.4.4 Waste Acceptance Documentation (WBS 4.40) . . . . . . 14

2.3.4.5 Storage Design/Construction (WBS No. 4.50) .......... 14

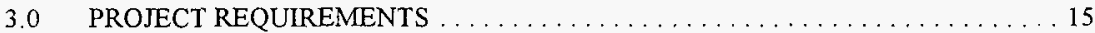

3.1 Packaging Design Criteria .............................. 15

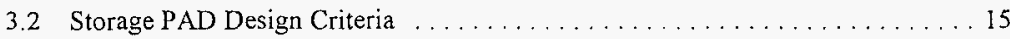

3.3 Criteria Imposed by Orders, Codes, Standards and Operating Procedures . . . . 15

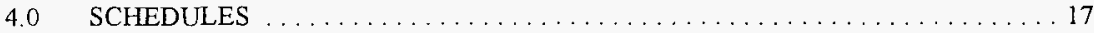

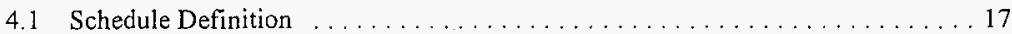

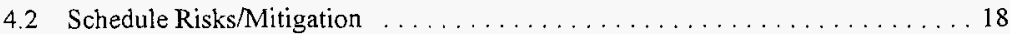

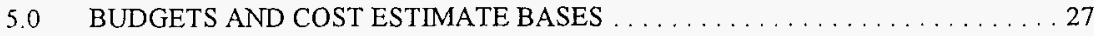

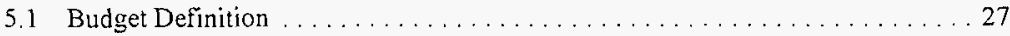

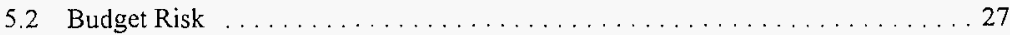

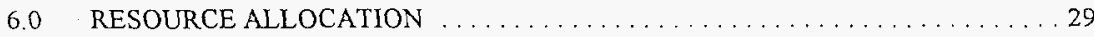

7.0 ENVIRONMENTAL SAFETY AND HEALTH $\ldots \ldots \ldots \ldots \ldots \ldots \ldots \ldots \ldots$

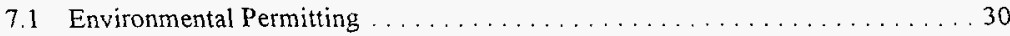

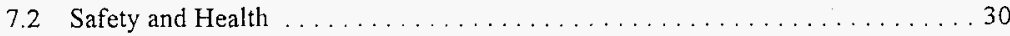

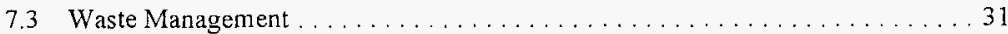

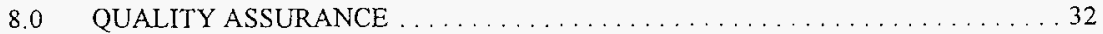


HNF-SD-SPJ-PMP-001

Rev. 0

TABLE OF CONTENTS (CONTINUED)

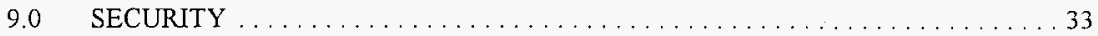

10.0 MANAGEMENT, PLANNING, AND CONTROL $\ldots \ldots \ldots \ldots \ldots \ldots \ldots \ldots \ldots$

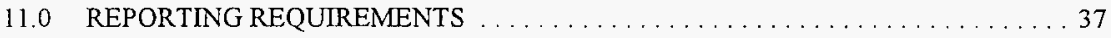

12.0 CONFIGURATION MANAGEMENT/SYSTEM ENGINEERING $\ldots \ldots \ldots \ldots .$.

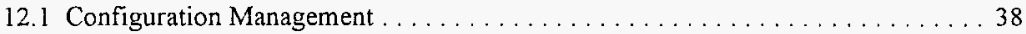

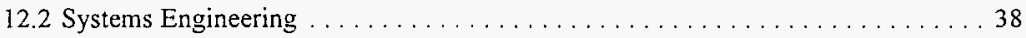

13.0 CHANGE CONTROL . . . . . . . . . . . . . . . . . . . . . . . . . 39

I4.0 READINESS DETERMINATION PLAN $\ldots \ldots \ldots \ldots \ldots \ldots \ldots \ldots \ldots \ldots$

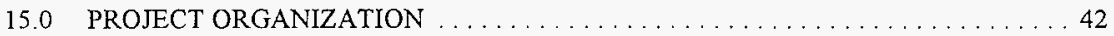


HNF-SD-SPJ-PMP-001

Rev, 0

\section{LIST OF FIGURES}

FIGURE

PAGE

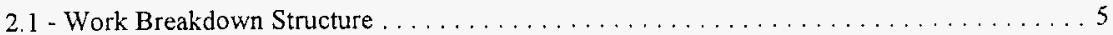

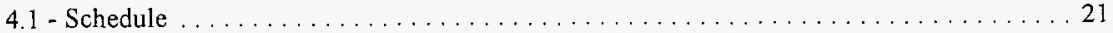

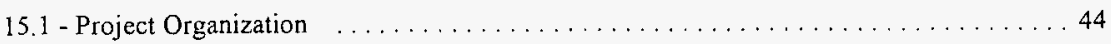


HNF-SD-SPJ-PMP-001

Rev. 0

\section{LIST OF TABLES}

TABLE

PAGE

3-3 DOE Orders/Codes/Standards/Hanford Operation Procedures $\ldots \ldots \ldots \ldots \ldots \ldots$

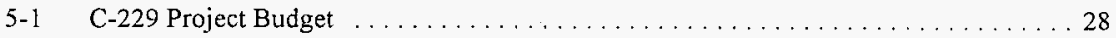

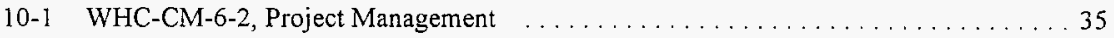

10-2 WHC-CM-2-5, Management Control System ..................... 36

15-1 Responsibility Assignment Matrix . . . . . . . . . . . . . . . . . . 45

15-2 Key Documents/Approval Requirements ................... 48 


\section{FRG SEALED ISOTOPIC HEAT SOURCES PROJECT (C-229) PROJECT MLNAGEMIENT PLAN}

\subsection{PROJECT OBJECTIVES}

\subsection{PURPOSE}

This Project Management Plan (PMP), BWHC-SD-C229-PMP-0001, serves as the top level document which defines/identifies the project scope, project objectives, organizational responsibilities, risk mitigation, control systems and procedures, and methods of performance for the successful execution of the Federal Republic of Germany (FRG) Sealed Isotopic Heat Sources Project, (C-229).

This PMP also defines work scope, schedule of activities, and estimated budgets for activities. Most importantly, the PMP will ensure that all appropriate consideration be given to DOE and other federal requirements as the DOE takes sole responsibility for the long term storage of this waste material.

Project C-229 is an integrated project managed by the B\&W Hanford Company (BWHC). Major project activities will be conducted by personnel from the 324 Building, BWHC; Solid Waste, Rust Federal Services Hanford (RFSH); and, Fluor Daniel Northwest (FDNW).

Additional personnel supporting the project are matrixed from various organizations within $\mathrm{B} \& \mathrm{~W}$ Protec (BWP), DynCorp, and other BWHC, RFS, and FDNW organizations.

\subsection{BACKGROUND}

In 1984, the U.S. Department of Energy (DOE) and the Federal Minister for Research and Technology of the Federal Republic of Germany (FRG) entered into a joint program for the development of processes for the treatment and immobilization of high-level radioactive waste. One element of this program was the production of thirty (30) sealed isotopic heat source canisters 
(sources). These sources were manufactured in the 324 Building B-Cell during three melter runs completed in 1988. Currently, these sources, along with two similar instnumented sources and associated production wastes (two additional canisters), are stored in the 324 Building A-Cell. This is a total of 34 canisters. Originally, the sources were to be transported to Germany for use in experimental programs associated with development of geologic storage facilities. These research efforts have been canceled, and an agreement has been reached between the DOE and FRG that the FRG will provide acceptable transportation and storage casks and sufficient funding for removal, transportation, interim storage, and ultimate disposition by DOE. Until such time that a permanent storage facility for wastes of this type is available, the sources will be relocated to the 200 West Area of the Hanford Site for Interim Storage. These sources have been classified as non regulated remote handled transuranic sealed isotopic heat sources.

\subsection{SCOPE}

The FRG Sealed Isotopic Heat Sources Project has been chartered to effect removal of the sources (canisters) from the 324 Building and relocate the sources to a storage site within the 200 West Area of the Hanford Site. Major activities include:

- Obtain shipping casks from the FRG.

- Preparation of environmental/safety documentation

- Prepare 324 Building cells for source removal/loading.

- Retrieval of the sources from A-Cell.

- Loading the sources into transportation/storage casks

- Construction of an interim storage site in the 200 West Area.

- Transportation of sources/casks to the Storage Site

- Decommissioning of cell production equipment

- Clean out of A-Cell.

- Project management.

- Path forward activities (to be identified). 


\section{HNF-SD-SPJ-PMP-001}

Rev. 0

Under the current scope, C-229 project management responsibility for the sources will end after the loaded storage casks have been successfully placed at the storage site. At this time, management of the sources will be the responsibility of Solid Waste Operations under RFSH. Once the sources are relocated to the storage site in the 200 West Area, they will remain at the interim storage site until a final disposal pathway is established. This could be a national repository or additional processing on site. Flour Daniel Hanford Company has the responsibility for developing a management strategy for the final disposition of the sources and other related path forvard activities.

\subsection{TECHNICAL OBJECTIVES}

The primary technical objective of this project is to retrieve the sources presently stored in a water-jacketed (dry) cooling system within the 324 Building A-Cell and to place them into a dry interim storage condition at the 200 West Area Central Waste Complex (CWC). The casks and storage site are to have a minimum life of 20 years. At the interim storage site, the casks are to be placed in covered storage to prevent corrosion of the cast iron casks. Although no internal cask inspections will be performed, routine site and cask external inspections are to be performed to insure the casks and site are maintained properly. Cask integrity is important to ensure the casks will be a viable shipping container at the end of the interim storage phase.

In addition, the project will remove from the 324 Building, and properly dispose of, equipment used in the manufacture of the sources. Minor repairs of 324 Building equipment will be effected to permit safe and timely retricval and to vacatc those presently utilized areas in a safe configuration. Since the 324 Building is to be deactivated, refurbishment of building systems (e.g., cell windorvs) to facilitate any future activities (other than safe decontamination and decommissioning) is specifically excluded from this project's scope. 


\section{Rev. 0}

\subsection{SCHEDULE OBJECTIVES}

Relocation of the sources from the 324 Building to the 200 West Area has been identified as a performance agreement (PA) for BWHC. Due to other ongoing and high priority decontamination and deactivation within the 324 Building, the schedule is closely integrated and dependent upon these other activities. The primary schedule objective is to integrate project activities with other 324 Building projects in such a manner to allow successful completion of the PA while minimizing impacts to other building activities. Present planning provides for the successful completion of the PA by removal of the sources from the 324 Building by August 1997.

\subsection{BUDGET OBJECTIVES}

Funding of $55.5 \mathrm{M}$ and delivery of necessary transport/storage casks have been provided by the FRG for the execution of this project and follow-on waste storage, handling, transportation, and final disposition. The budget for the execution of Project $\mathrm{C}-229$ activities under BWHC management is $\$ 3,400,000$ (including contingency). 
HNF-SD-SPJ-PMP-001

Rev. 0

\section{$2.0 \quad$ STATEMENT OF WORK SCOPE}

\subsection{PROJECT OBJECTIVES}

The objectives of Project C-229, FRG Sealed Isotopic Heat Sources Project, are:

- Acquire acceptable waste transport and storage casks;

- Execute necessary waste acceptance documentation to allow for the transfer of custody for the sources from the 324 Building to Solid Waste Operations;

- Effect the safe retrieval, packaging, and transport of the sources from the 324 Building to the 200 West Area interim storage site;

- Provide criteria for, location of, design, and construction of a waste storage site;

- Transfer management responsibility for the stored sources to Solid Waste Operations; and,

- Decontaminate and decommission manufacturing equipment within the 324 Building associated with the production of sources.

- Clean-up of hot cells utilized during production of the sources

Since the 324 Building is being decommissioned, repair and restoration of damage to noncritical hot cell systems caused by the storage of this material in the 324 Building A-Cell is not a requirement and is specifically excluded scope.

This project is being closely coordinated with other deactivation and clean out campaigns ongoing within the 324 Building. Present schedule interfaces indicate that access to the A-Cell for retrieval of the sources will be available when the air-lock is not being utilized for B-Cell clean out activities. Final clean out of the source manufacturing equipment is presently scheduled to be completed after the start of FY-1998.

\subsection{WORK BREAKDOWN STRUCTURE}

Figure 2.1 presents the work breakdown structure (WBS) for Project C-229. 


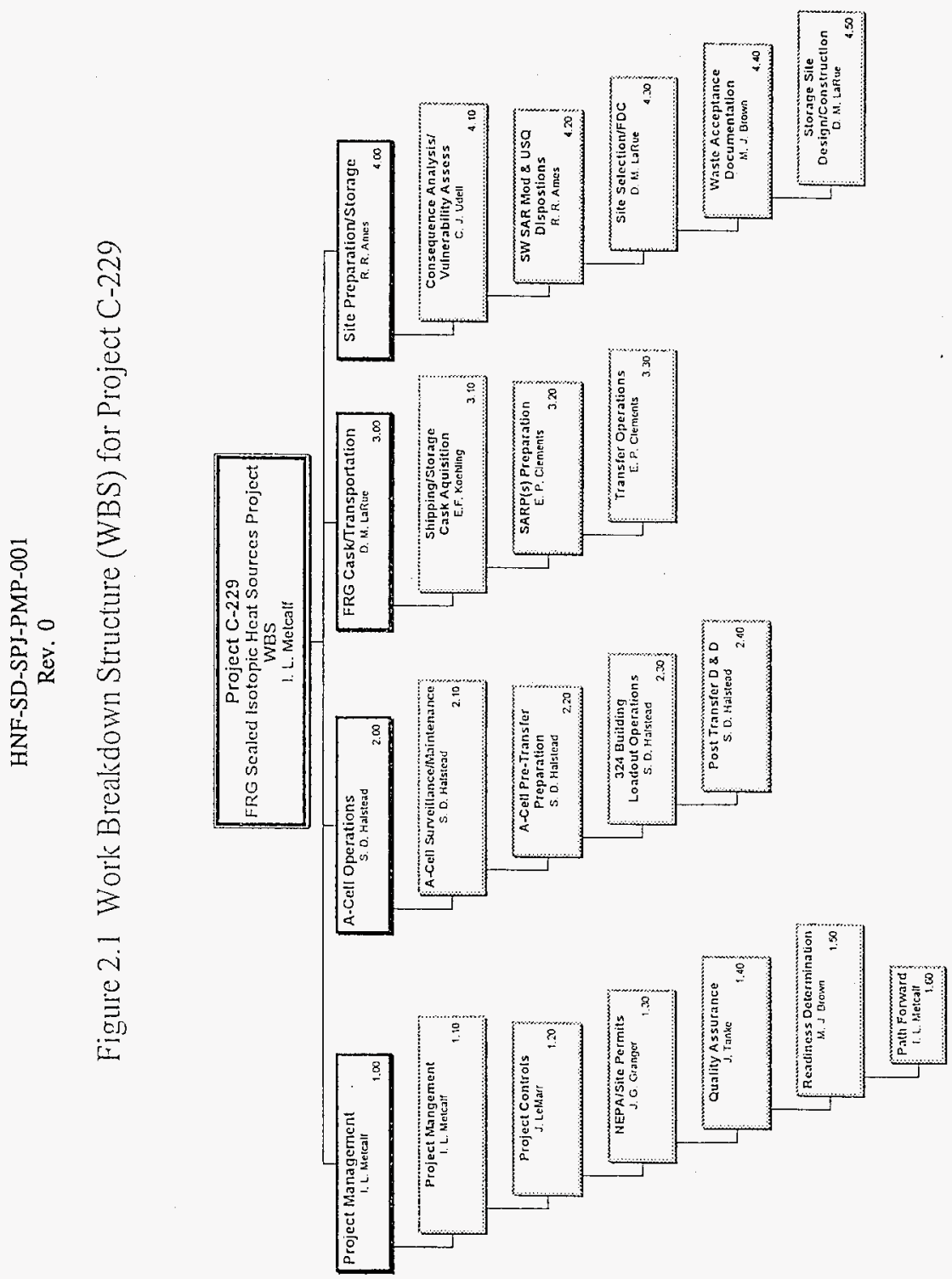




\subsection{WBS DICTIONARY}

The discussion below defines the work scope of the various WBS elements. Additional detail for each WBS element is provided in Task/Activity Planning Sheets developed for the project. Schedule and budget risks are addressed in sections 4.2 and 5.2, respectively.

\subsubsection{Project Management (WBS No. 1.00)}

This major sub-division of work contains all the elements associated with the overall management of the project. It includes general project management, project controls, quality assurance, and the project readiness assessment. Also included within this WBS is the preparation of project NEPA documentation.

\subsubsection{Project Management (WBS No, 1.10)}

This element of the WBS encompasses all activities associated with project management of Project C-229. The major activities included within this WBS are to provide overall project coordination and customer interface. Overall project management responsibility has been assigned by Fluor Daniel Hanford (FDH) to BWHC, 300 Area Transition Projects. The project is being executed as an integrated project with assisting project personnel being matrixed from FDNW, RFSH, and DynCorp. This project management plan (PMP) is being prepared to document the activities of this main element and all other elements of Project C-229. Most importantly, the project will ensure that all appropriate consideration be given to DOE and other federal requirements as the DOE takes on sole responsibility for the long term storage of this material 
HNF-SD-SPJ-PMP-001

Rev. 0

\subsubsection{Project Controls (WBS No. 1.20)}

This WBS element is responsible for maintaining project schedules/budgets and overall project reporting. Specific responsibilities in these areas include:

Identification of all necessary activities at the working level and scheduling these activities in a logical, cost effective manner from which a critical path schedule can be developed.

Establishment of cost estimates for all major project subelements, allocation of funding to project activities, and oversight of budget expenditures against earned value.

This task entails all formal and informal project statising and reporting within the project team, appropriate Hanford contractor management, and RL management.

\subsubsection{NEPA/Site Permits (WBS No. 1.30)}

This task provides for the activities necessary to the preparation and approval of all NEPA documentation and other appropriate permits and/or permit submittals associated with the execution of this project. Specific activities include preparing NEPA documentation for the storage location in the 200 West Area, conducting an environmental requirements checklist, and addressing any requirements identified by the checklist.

\subsubsection{Quality Assurance (WBS No. 1.40)}

A project specific Quality Assurance Plan (QAPP) will be generated and followed during the execution of this project. Since this project involves certain reasonably high-risk non-routine activities, it is deemed essential that quality assurance/safety concerns be afforded immediate and complete attention. The preparation and adherence to a QAPP will increase the potential of cost 
effective, safe, and timely execution of this project. Included within this element are the development of an acceptance test plan, witnessing of testing, and acceptance of the FRG manufactured transportation/storage casks.

\subsubsection{Readiness Determination (WBS No. 1.50)}

This element of the project includes the readiness determination for the various operational aspects of the project. It will ensure that an appropriate determination is conducted for each of three project functional areas: 324 Building Loadout activities, transportation from the 324 Building to the 200 West Area activities, and storage activities. Specific activities include preparation of a readiness determination plan which details the actions which will be conducted during the determination (including the definition of roles and responsibilities for the various organizations which will be involved with the determination of project readiness) and completion of the readiness determination.

\subsubsection{Path Forward (WBS No. 1.60)}

The isotopic heat sources are to be transferred to the $\mathrm{CWC}$ for interim storage as remote handled transuranic waste. Future reclassification is possible, and the final disposition (i.e., high level waste repository, subsequent processing, etc.) is uncertain as of this date. However, Fluor Daniel Hanford and B\&W Hanford Company are committed to the path forward for this material. Because this path and the corresponding scope and schedule are uncertain, and may remain so for quite some time, resources, budget, milestones, schedules, etc., have not been included in this project management plan. The only activity to date was to include the heat sources on the Systems Engineering list of issues. Candidate scope may include: additional waste characterization, disposition of process data, additional 324 Building clean out stabilization, systems engineering and life cycle analysis, and site waste forecasts. Change control action will be undertaken commensurate with evolving direction from RL. 
HNF-SD-SPJ-PMP-001

Rev, 0

\subsubsection{A-Cell Operations (WBS No. 2.00)}

This major subdivision of work encompasses all activities within the 324 Building associated with the present storage of the sources, i.e., preparation for packaging, packaging and load-out, and post-transfer decontamination and decommissioning of equipment used in the manufacture of the sources.

\subsubsection{A-Cell Pre-Transfer Preparation (WBS No. 2.10)}

This element of work provides for preparation of the 324 Building A-Cell for loadout of the sources into the transportation/storage casks. Specific activities include refurbishment of the A-Cell crane, installation monitoring equipment within the cell (i.e. video camera, dosimetry), manipulator repairs (if required), etc. The shielding door to the 324 Building A-Cell also might need minor repairs (hinge pin replacement, seal replacement, etc.)

\subsubsection{324 Building Loadout Activities (WBS No. 2.20)}

This WBS element contains the work activities to be conducted within the 324 Building which are necessary to load the sources into casks and preparation of the casks for shipment. Specific activities include the surface decontamination of the REC airlock, preparation of the shipping/storage casks, placing the sources into the casks, and preparing the casks for shipment

Project specific procedures, which will be required for the loadout of the sources, will be prepared under this WBS. In addition, procedure prove out and staff qualifications, which will be necessary, are included in this WBS 
HNF-SD-SPJ-PMP-001

Rev. 0

\subsubsection{Post-Transfer Decontamination and Decommissioning} (WBS No. 2.30)

This element of work provides for the removal of processing/storage equipment which will be remaining after the removal of the sources. Specific activities include the removal and size reduction of production/storage equipment, packaging/disposal of the size reduced equipment, and general hot cell clean out, paint cleanup, and repainting, etc.).

\subsubsection{Cask/Transportation (WBS No. 3.00)}

This major sub-division of work contains all the elements associated with the modification and acquisition of the cask systems for transport and storage of the sources. It includes appropriate safety analyses for the cask systems to be used for transfer operations (pre and post storage) and the actual transfer operations of the casks from the 324 Building to the 200 West Area.

\subsubsection{Shipping/Storage Cask Acquisition (WBS No. 3.10)}

This element includes all activities associated with review of the German design, any necessary design modifications, and coordination of the shipment of the shipping/storage casks from Germany to the Hanford Site. Specific activities associated with the actual acceptance inspection of these casks is contained within WBS element 1.30 Quality Assurance. Interim storage of the empty casks is also included in this sub-element of work. 
HNF-SD-SPJ-PMP-001

Rev. 0

\subsubsection{SARP(s) Preparation (WBS No. 3.20)}

This element of work includes the development and finalization of packaging design criteria documentation (PDC), safety analyses for transport, and all safety review and analyses associated with the certification for use and use of the German transportation cask systems. An individual SARP will be prepared for both the Castor and the GNS-12 Cask designs. Future work scope includes: an engineering change notice (ECN) and corresponding supporting analyses to revise the two SARPs to allow transfer from the interim storage site to the future Hanford transloading or processing facility.

\subsubsection{Transfer Operations (WBS No. 3.30)}

This WBS element is comprised of all transportation activities necessary to move the loaded casks from the 324 Building to the 200 West Area storage location. This is inclusive of transportation planning, rail/highway transport, and placement in the storage facility. This task also includes all activities associated with hoisting and rigging of waste casks onto the storage site. Dual lifts will be required if road transfer is also required to gain access to the final waste storage site

\subsubsection{Site Preparation/Storage (WBS No. 4.00)}

This main element of work includes all activities associated with acceptance of the heat sources, storage site selection, and design and construction of the interim storage site. Maintenance of the site during storage is excluded from this project. Project C-229 responsibility for the sources will terminate at the point of completion of transfer to the interim storage site. Funding sufficient for the long term surveillance and maintenance of the sources will be provided directly from DOE to RFSH 
HNF-SD-SPJ-PMP-001

Rev. 0

\subsubsection{Consequence Analysis/Vulnerability Assessment} (WBS No. 4.10)

This element of work includes the performance of a consequence analysis performed by Hanford Site Security. At the completion of the consequence analysis, a vulnerability assessment (VA) will be performed if deemed requisite. The recommended additional security requirements from the $\mathrm{CA}$ and/or VA will be incorporated into the functional design criteria documentation for the waste storage site.

\subsubsection{Solid Waste SAR Modifications and USQ Disposition (WBS No.4.20)}

An assessment will be made of the Central Waste Complex (CWC) Interim Safety Basis Document against the conditions imposed by the sources (in storage casks), a remote handled transuranic waste. Any unresolved safety questions (USQs) will be identified and dispositioned. Criteria from this assessment will be fed into the design requirements for the storage site. An engineering change notice (ECN) will be processed against the Interim Safety Basis Document to reflect the safe and satisfactory storage of the sources within the CWC.

\subsubsection{Site Selection/Functional Design Criteria (WBS No. 4.30)}

This task will utilize information gathered from 3.10 (CANA) and 3.20 (SW SAR Mod and USQ Disp), along with other appropriate DOE and Hanford specific requirements to perform a site selection study. At the completion, and approval of the site selection, the functional design criteria document for the waste storage site will be prepared and approved. 
Rev. 0

\subsubsection{Waste Acceptance Documentation (WBS No. 4.40)}

This task includes all activities associated with preparation and approval of waste acceptance documentation to permit the safe and compliant transfer of the sources into the CWC. Also included in this task will be any necessary documentation associated with acceptance of the installed waste storage site, and preparation of and training to procedures for the storage of the waste will be performed.

\subsubsection{Storage Site Design/Construction (WBS No. 4.50)}

This task will perform the design and construction activities associated with the storage site for the casks containing the sources. Design and construction will be to the requirements as identified in the functional design criteria (3.30). 
Rev. 0

\subsection{PROJECT REQUIRENENTS}

\subsection{PACKAGING DESIGN CRITERIA}

The packaging requirements or design criteria are contained within two approved documents. The design criteria for the Castor GSF system (five source overpack) is contained in "Castor GSF Packaging Design Criteria," WHC-SD-TP-PDC-032, Rev. 0, August 1996. The design criteria for the GNS-12 Cask (three source overpack) is contained in "GNS-12 Cask Packaging Design Criteria," WHC-SD-TP-PDC-033, Rev. 1, July 1996.

\subsection{STORAGE PAD DESIGN CRITERIA}

A functional design criteria (FDC) document will be prepared to define the requirements for design and construction of the interim storage site. Definitive design activities for the site will not commence until completion of this FDC document.

\subsection{CRUTERIA IMPOSED BY ORDERS, CODES, STANDARDS AND OPERATING PROCEDURES}

Detailed requirements are identified within the Packaging Design Criteria (Section 3.1) and the Functional Design Criteria (Section 3.2).

The following is a list of overlying orders, codes, standards, and Hanford operating procedures: 
HNF-SD-SPJ-PMP-001

Rev. 0

Table 3-1. DOE Orders/Codes/Standards/Hanford Operating Procedures

\begin{tabular}{|c|c|}
\hline \multirow[t]{10}{*}{ DOE Orders } & DOE O 430.1, "Life Cycle Asset Management," \\
\hline & DOE O 460.1, "Packaging and Transportation Safety" \\
\hline & DOE O 5480.19, "Conduct of Operations for DOE Facilities" \\
\hline & DOE O 5480.21, "Unreviewed Safety Questions" \\
\hline & DOE O 5480.22, "Technical Safety Requirements" \\
\hline & DOE O 5480.23, "Nuclear Safety Analysis Reports" \\
\hline & DOE O 5480.31, "Startup and Restart of Nuclear Facilities" \\
\hline & $\begin{array}{l}\text { RLID } 5480.31 \text {, "Startup and Restart of Facilities Operational Readiness Review and } \\
\text { Readiness Assessments }\end{array}$ \\
\hline & DOE O 5820.2A, "Radioactive Waste Management" \\
\hline & DOE O 6430.1A, "Genera! Design Criteria" \\
\hline \multirow[t]{4}{*}{ CODES } & WAC 173-303, "Washington Dangerous Waste Regulations" \\
\hline & 49 CFR $171-173$ \\
\hline & 10 CFR 71, "LAEA" \\
\hline & 10 CFR 830, "Nuclear Safety Management" \\
\hline \multirow[t]{2}{*}{ STANDARDS } & $\begin{array}{l}\text { DOE STD 1027-92, "Hazard Categorization and Accident Analysis Techniques for } \\
\text { Compliance with DOE O 5480.23, Nuclear Safety Analysis Report" }\end{array}$ \\
\hline & DOE STD 3006-93, "Planning and Conduct of ORRs" \\
\hline \multirow[t]{9}{*}{ HANFORD PRACTICES } & WHC-EP-0063-4, "Hanford Site Solid Waste Acceptance Criteria" \\
\hline & WHC-CM-1-10, "Safety Manual" \\
\hline & WHC-CM-2-14, "Hazardous Material Packaging and Shipping" \\
\hline & WH-IC-CM-7-5, "Environmental Compliance" \\
\hline & WHC-CM-4-27, "Radiological Control Practices and Procedures" \\
\hline & WHC-CM-4-40, "Industrial Hygiene Manual" \\
\hline & PNL-SAR-324, "324 Building Safety Analysis Report" \\
\hline & Hanford Radiological Control Manual \\
\hline & Hanford Site Hoisting and Rigging Munual \\
\hline
\end{tabular}


Rev. 0

\subsection{SCHEDULES}

\subsection{SCHEDULE DEFINITION}

The project's summary schedule is presented in Figure 4-1. A detailed working schedule has been prepared, which logically ties specific activities and identifies the critical path for the project. The project's schedule is closely integrated with other 324 Building activities. Key projects which must be interfaced with for the successful completion of C-229 include: 324 Building B-Cell Safety Clean out Project, Cesium Legacy Project, and 324 Building Surveillance and Maintenance. 324 Building personnel prepare an integrated facility schedule which identifies key interfaces between projects and shows use of critical facility resources, such as the REC airlock and cask handling area. Key schedule activities are as follows:

\section{ACTIVITY}

A-Cell/Airlock Prep

Storage Site Design/Construction

SW SAR and USQD

RL Approval of USQD and ECN to SAR

Submittal of Readiness Determination

Documentation to RL

Approval for Readiness by RL

NEPA Approval

Transfer of sources complete

\section{COMPLETE}

May 1997

June 1997

April 1997

May 1997

June 1997

June 1997

April 1997

August 1997 
HNF-SD-SPJ-PMP-001

Rev. 0

\subsection{SCHEDULE RISKS/MITIGATION}

The project's overall schedule is aggressive and is planned to complete removal of the sources from the 324 Building in FY-1997. In preparing the schedule, several assumptions were necessary regarding the interactions between activities. These assumptions are:

- The project will be allowed to design the storage facility prior to the approval of the storage EA. (Note: No construction activities will occur until the EA record of decision (ROD) is issued).

- The construction of the storage facility will be allowed prior to the RL approval of the ECN to the CWC safety basis. (Note: The storage facility will not accept the sources until after the ECN is approved by $\mathrm{RL}$ ).

The project schedule contains several areas of risk which will require a large degree of management control due to their potential for project delay. The specific risks are:

- Actual retrieval operations within the 324 Building are tied closely to other ongoing clean-out operations. Access to the air lock within the hot cell area must occur on schedule and with sufficient duration to allow air lock decontamination, A-Cell preparatory activities, and sources load-out.

This schedule risk is minimized by project staff working closely with 324 Building management and project staff from other projects to closely integrate the potential conflicting activities between projects. 
HNF-SD-SPJ-PMP-001

Rev. 0

- Completion and approval of an Unreviewed Safety Question Determination (USQD) and Engineering Change Notice (ECN) for the Interim Safety Basis Document for CWV needs to be completed and approved by RL prior to acceptance of the sources at the new storage site. Delay in approval will result in delay of waste removal activities

To minimize the time required for RL acceptance of the ECN, key individuals from RL are routinely briefed on project status and necessary actions. This allows advanced planning for review cycles to maintain review times to a minimum.

- Completion of the Readiness Determination is critical to achievement of schedule. Active participation by all organizations in the definition of readiness determination organizational roles and responsibilities, requirements, and timely review and approval of the readiness determination by FDH will be required if the project schedule is to be met.

The project team will prepare a readiness determination plan which will clearly identify the roles and responsibilities of various Hanford Site organizations. The readiness determination plan will also detail the requirements (technical, training, environmental, and approval) necessary to determine the readiness of the shipping and receiving facilities. Concurrence from the organizations will minimize review times and eliminate redundant actions.

- Completion and approval of the Environmental Assessment (EA) for the storage site in the 200 West Area CWC is necessary prior to initiating any construction activities. Any delays in the preparation or approval of the EA could create a resulting delay in the preparation activities, causing an overall delay in the project. 


\section{HNF-SD-SPJ-PMP-001}

Rev. 0

The EA for the project will be prepared based upon an EA previously initiated (but not completed) for special case waste storage, which included the sources in the estimated inventory. This may minimize the preparation time for the document. In addition, RL NEPA staff will be consulted early in the process to reduce the possibility of missing any requirements. 
Figure 4-1 - Schedule

HNF-SD-SPJ-PMP-001

Rev. 0

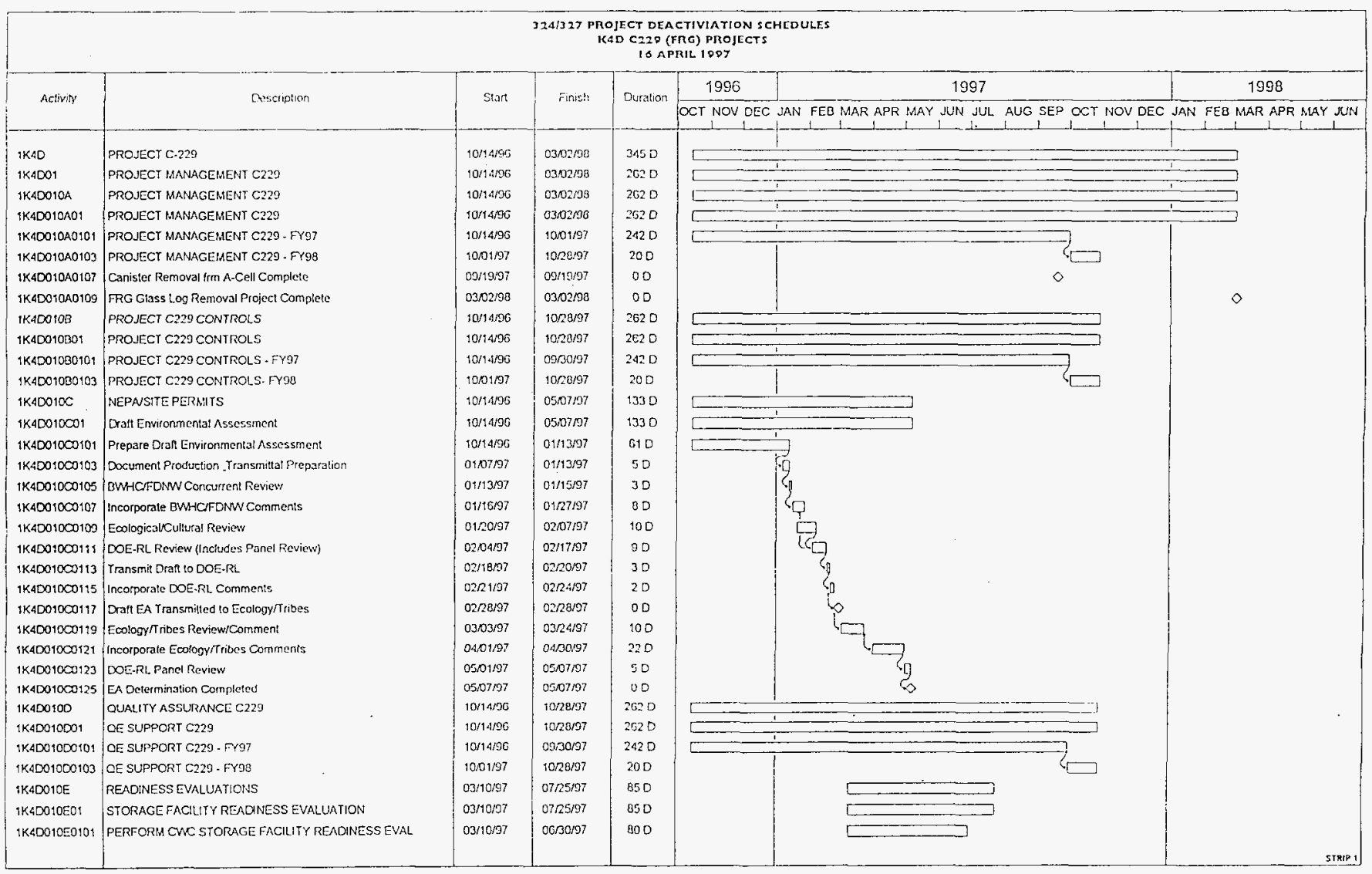




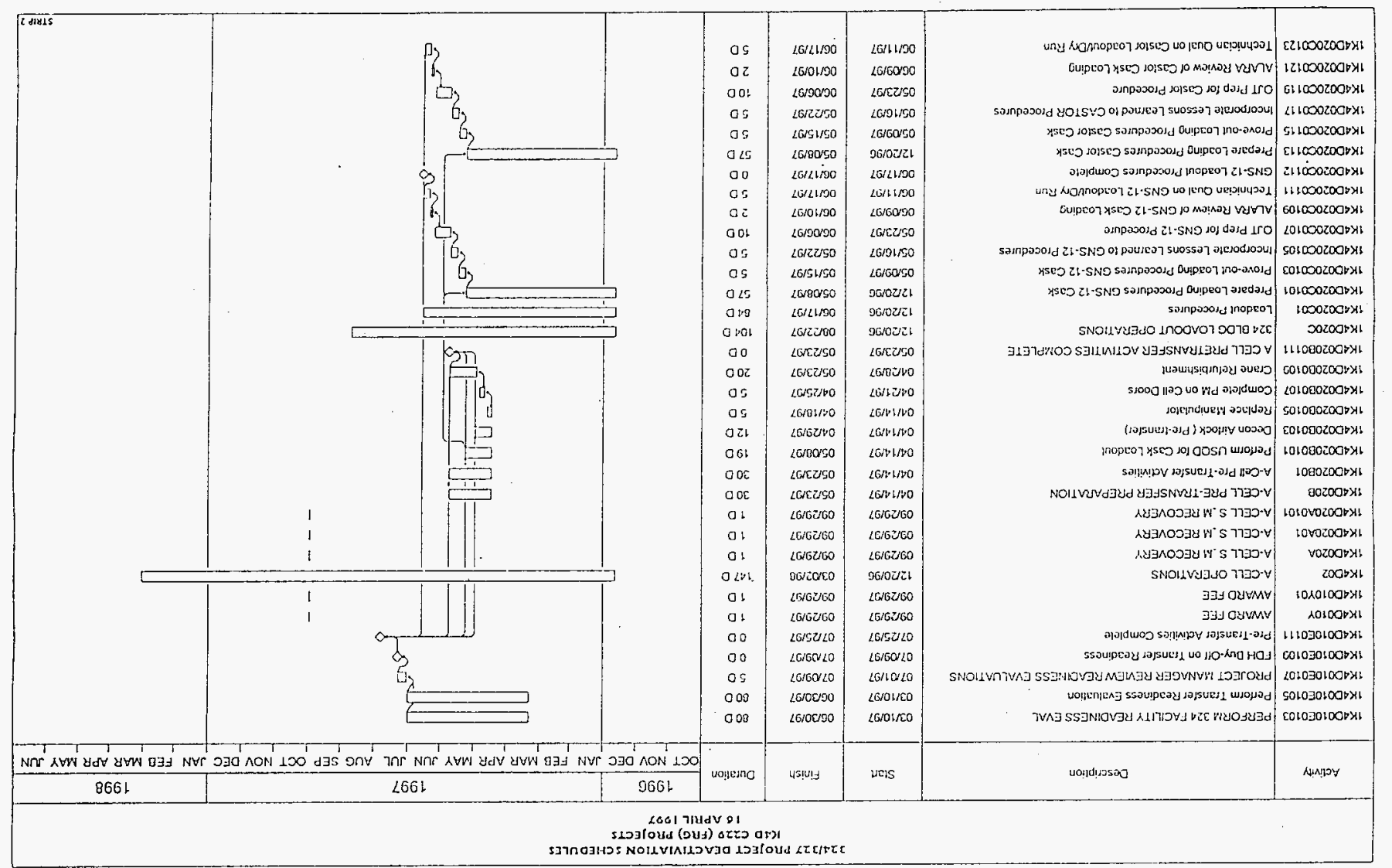


Figure 4-1 - Schedule

HNF-SD-SPJ-PMP-001

Rev. 0

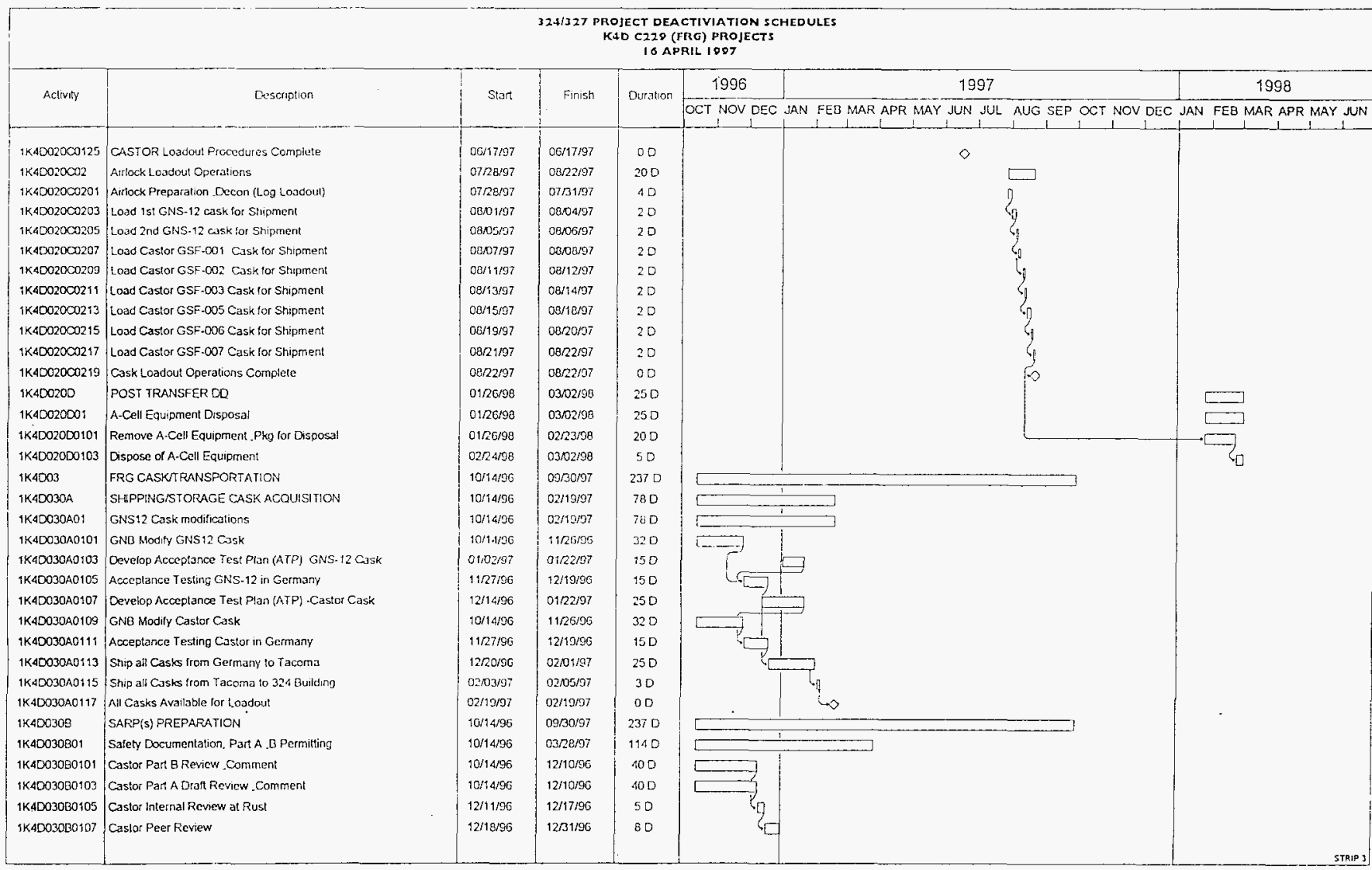




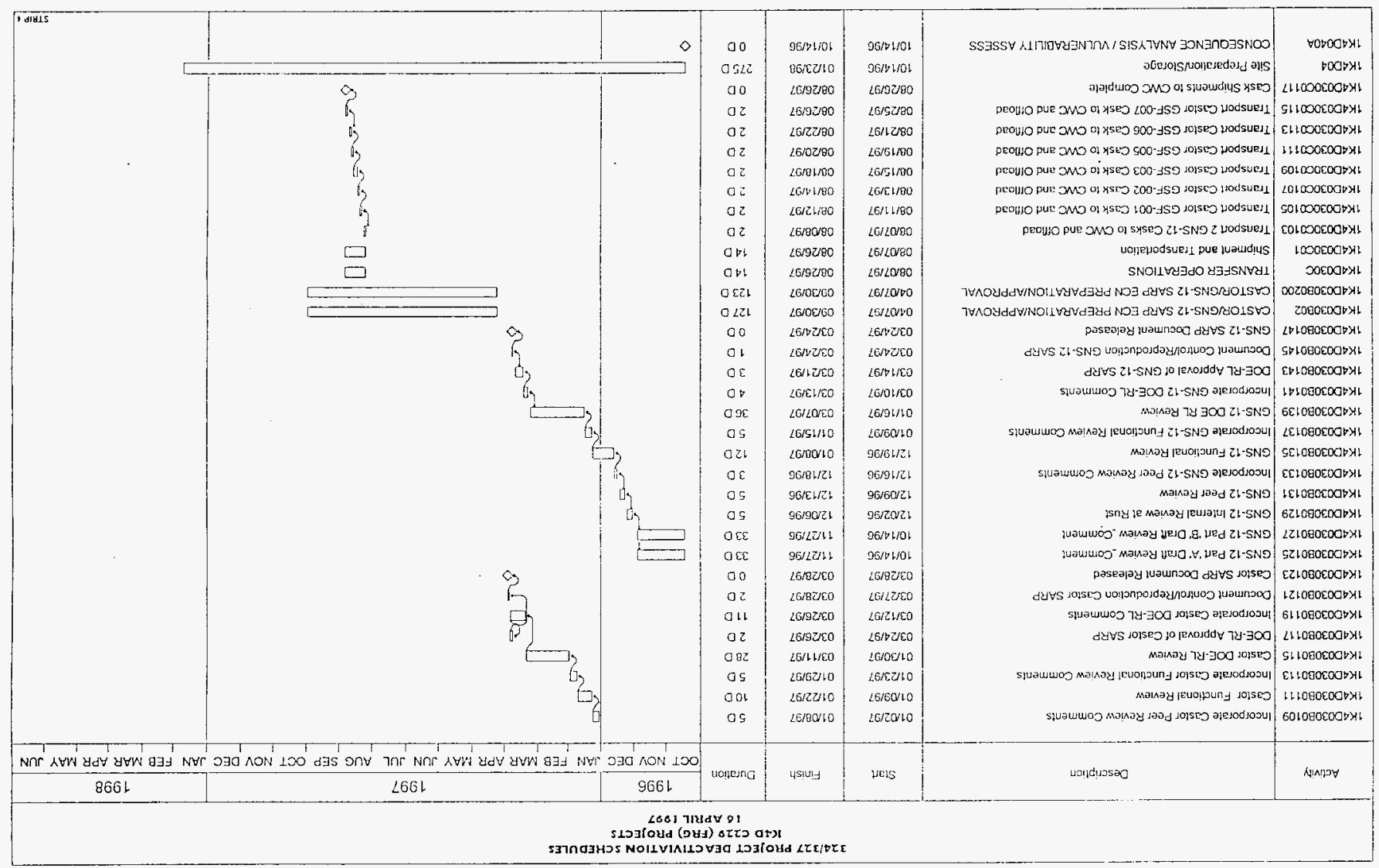


Figure 4-1 - Schedule

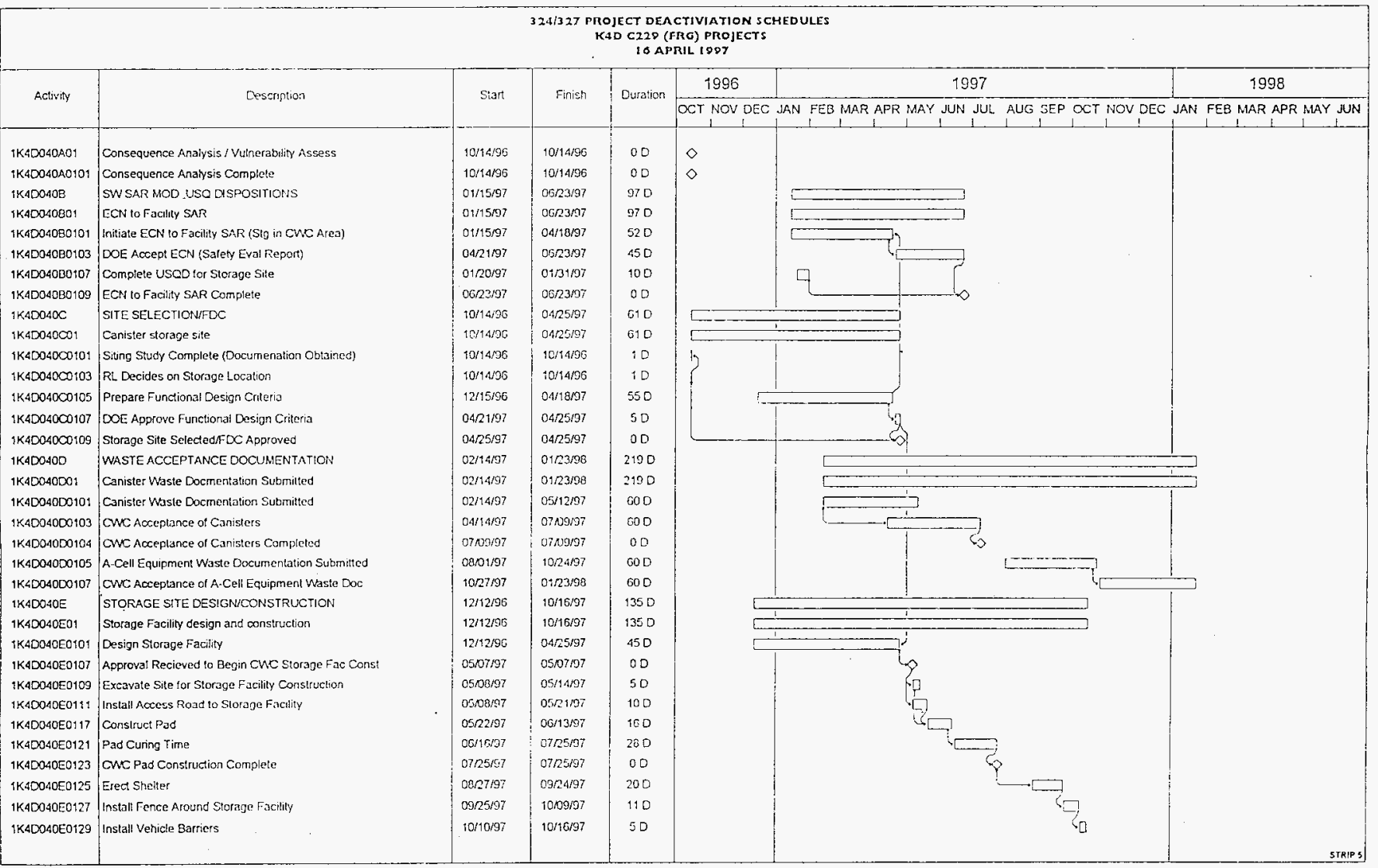


Figure 4-1 - ScheduTe

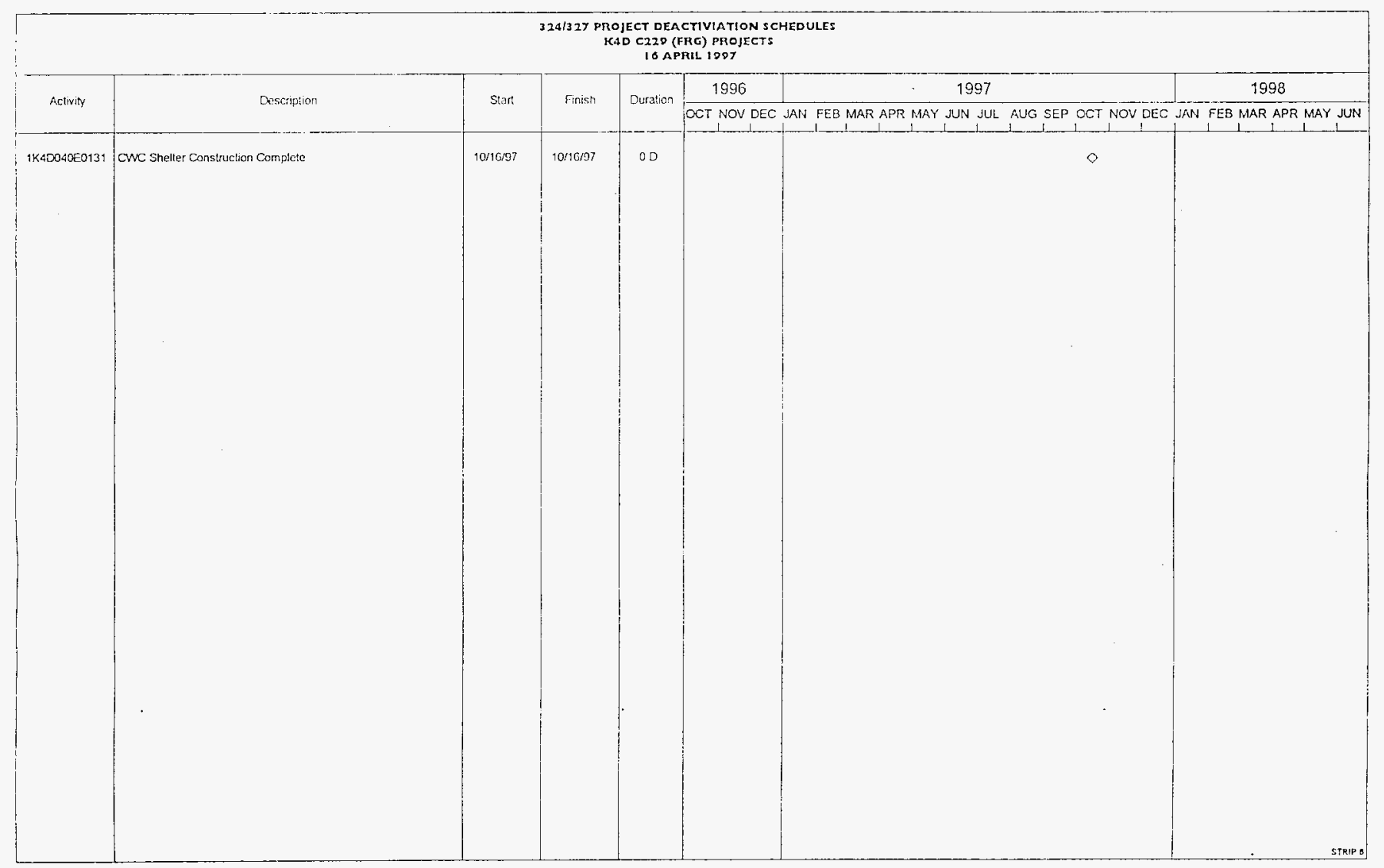




\section{HNF-SD-SPJ-PMP-001}

Rev. 0

\subsection{BUDGETS AND COST ESTIMATE BASES}

\subsection{BUDGET DEFINITION}

The project's estimated budget is presented in Table 5-1, C-229 Project Budget. Estimates are based on performer generated activity estimates, where available. Storage site design and construction costs are engineering allowances and will be updated as the requirements and site location become finalized. The total estimated cost for the project activities (including contingency) is $\$ 3,400,000$. This estimate is based on present rates and contains no escalation.

\subsection{BUDGET RISK}

The project budget was developed using an activity-based cost approach at the working level. Where detailed information was not available, engineering estimates were made based on the knowledge and expertise of project staff. It is not expected that there are any budget areas which represent an unusually high risk to the project. However, in preparing the estimate, the following assumptions were made:

- The casks provided by the FRG will be acceptable for transportation and storage of the sources without modification once they are accepted by BWHC.

- Once the A-Cell shielding door and crane are repaired, they will not require any additionat repair or maintenance.

- The Hanford rail system will be available for the transfer of the loaded casks from the 324 Building to the 200 West Area.

- The sources will be declared a waste material and be acceptable for storage at the selected site within the CWC.

- Funding for surveillance and maintenance during long term storage at the CWC will be 
HNF-SD-SPJ-PMP-001

Rev. 0

provided to Waste Management directly from RL.

Table 5-1 C-229 Project Budget

\begin{tabular}{|c|c|}
\hline \multicolumn{2}{|l|}{ WBS 1.00 Project Management } \\
\hline Project Management & $\$ 411,825$ \\
\hline Project Controls & $\$ 37,269$ \\
\hline NEPA/Site Permits & $\$ 71,430$ \\
\hline Quality Assurance & $\$ 54,082$ \\
\hline Readiness Determination & $\$ 143,020$ \\
\hline Path Forward & $\$ 0^{1}$ \\
\hline Award Fee & $\$ 170,00$ \\
\hline \multicolumn{2}{|l|}{ WBS 2.00 A-Cell Operations } \\
\hline A-Cell Surveillance and Maintenance & $\$ 300,036$ \\
\hline A-Cell Pre-transfer Preparation & $\$ 145,482$ \\
\hline 324 Building Loadout Operations & $\$ 196,776$ \\
\hline Post Transfer D\&D & $\$ 190,701$ \\
\hline \multicolumn{2}{|l|}{ WBS 3.00 FRG Casl/Transportation } \\
\hline Slipping/Storage Cask Acquisition & $\$ 170,001$ \\
\hline SARP Preparation & $\$ 328,061$ \\
\hline Transfer Operations & $\$ 118,341$ \\
\hline \multicolumn{2}{|l|}{ WBS 4.00 Site Preparation/Storage } \\
\hline Consequence Analysis/Vulnerability Assessment & $\$ 24,779$ \\
\hline Solid Waste SAR Mods/USQD & $\$ 90,859$ \\
\hline Site Selection/FDC & $\$ 38,234$ \\
\hline Waste Acceptance Documentation & $\$ 166,747$ \\
\hline Storage Site Design/Construction & $\$ 324,805$ \\
\hline Contingency & $\$ 411,761$ \\
\hline Total & $\$ 3,394,209$ \\
\hline
\end{tabular}

'Future activity to be funded as scope evolves. 


\section{HNF-SD-SPJ-PMP-001 \\ Rev. 0}

\subsection{RESOURCE ALLOCATION}

The personnel assigned to the performance of the various WBS activities will be allocated from existing program, project management, and core engineering functions. Review of resource requirements against present and projected personnel availability indicates no shortfalls requiring the acquisition of technical support from other than Hanford organizations.

Due to the small size of the construction effort, construction will most likely be performed by Hanford construction forces. A plant forces work review will be performed prior to initiation of the design activities.

All work activities will be pre-discussed and appropriately scheduled with applicable assigned organizational management prior to commencement of work or commitment to specific task schedules. 


\section{HNF-SD-SPJ-PMP-001}

Rev. 0

\subsection{ENVIRONMENTAL, SAFETY AND HEALTH}

\subsection{ENVIRONMENTAL PERMITTING}

A point of contact checklist will be generated for the project. All environmental permitting will be under the guidance provided by WHC-CM-7-5, "Environmental Compliance." An environmental assessment will be required for this project.

\subsection{SAFETY and HEALTH}

All operations will conform to the requirements as identified in section 3.3. All operations will be performed to the appropriate guidance manuals currently WHC-CM-1-10, "Safety Manual," WHC-CM-2-14, "Hazardous Materials Packaging and Shipping," WHC-CM-4-27, "Radiological Control Practices and Procedures," and WHC-CM-4-40, "Industrial Hygiene Manual." Construction activities will be performed under the additional guidance provided by the ICF KH "Environmental, Safety, and Health Program Manual," and (if applicable) the ICF KH "Contractor Environmental Safety and Health Program Manual."

Operations to be performed within the confines of the 324 Building will be planned, assessed, and executed under the guidance and safety envelope definition as defined in PNL-SAR324, "324 Building Safety Analysis Report." The future interim storage site will be folded into the safety envelope provided by WHC-SD-WM-ISB-002, "Solid Waste Burial Grounds Interim Safety Basis," depending upon the final site location determination.

The SARPs for the CASTOR and the GNS-12 will also dictate safety criteria for transport. 


\subsection{WASTE MANAGEMENT}

All wastes will be managed per the criteria defined in WHC-EP-0063-4, "Hanford Site Solid Waste Acceptance Criteria." In addition to the sources, project waste streams are expected to consist of low level waste generated during the repair of the A-Cell crane/loadout of the sources, low level waste generated from process equipment removal activities, and decontamination activities prior to/after source loadout.

Non-contaminated wastes generated by project activities will be disposed of through normal waste collection processes. Construction wastes (non-hazardous and hazardous) generated by the Hanford Site Construction forces for the storage pad will be managed and disposed of on the Hanford Site.

For the heat sources, specific waste summaries are to be prepared. 


\section{HNF-SD-SPJ-PMP-001}

Rev. 0

\subsection{QUALITY ASSURANCE}

The commitment to safety by the BWHC management dictates management and verification activities to ensure safety and environmental considerations are reflected in the various activities associated with the C-229 Project. For purposes of this document, quality assurance (QA) will be considered to be all of those planned and systematic actions necessary to provide adequate confidence that project activities will be performed satisfactorily

The C-229 Project will adhere to the applicable requirements of 10 CFR 830, "Nuclear Safety Management, Subpart A, General Provisions, Section 830.120, Quality Assurance Requirements" and other applicable requirements for transportation and storage of radioactive waste. In accordance with these requirements, the project will develop a project specific Quality Assurance Program Plan (QAPP) that implements the applicable requirements of the governing regulations and standards.

All project participants will be required to work to QA programs that are compatible with, and provide for, the applicable requirements identified in the QAPP. New QA programs need not be developed if existing QA programs can be shown to adequately cover the QAPP requirements Any new QA programs developed specifically to address requirements identified in the project specific QAPP are to be reviewed and approved prior to implementation.

QA requirements are to be imposed on activities associated with cask acquisition (refurbishment/modification, shipping, receiving, pre-operational testing, etc.), preparation and loading, transportation (safety reviews, transport, etc.), waste storage (siting, construction, etc.), and equipment decontamination and decommissioning (D\&D). These QA requirements are to be implemented using a "graded approach". Only those requirements applicable to a particular activity or task are to be imposed. The basis for decisions made in developing the "graded approach" will be included in the QAPP. 


\section{HNF-SD-SPJ-PMP-001}

Rev. 0

\subsection{SECURITY}

Security activities associated with Project C-229 are managed under the guidance provided by WHC-CM-4-33, "Security Manual."

No new security provisions are required for activities associated within the 324 Building, nor are any special security provisions required for transport of the casks containing waste materials to the interim storage site in the 200 West Area.

Security provisions may have to be designed into the waste storage site in the 200 West

Area. A consequence analysis (CA) will be performed to identify potential need for other than normal Hanford site security protection. Upon completion of the CA, and, if the results of the CA indicate the need for enhanced security provisions, a vulnerability assessment (VA) will be performed to identify needed cost-effective security provisions to be incorporated into the storage sites design criteria. 


\section{HNF-SD-SPJ-PMP-001}

Rev. 0

\subsection{MANAGEMENT, PLANNING, AND CONTROL}

This project is not funded through Congressional appropriation and, therefore, is not subject to Congressional mandates. The project is subject to requirements generally applicable to high expense DOE work with highly radioactive materials by DOE contractors. Table 10.1 and 10.2 identify specific procedural contractor requirements which have been determined to not be applicable and will not be followed during the course of project execution.

All other applicable project procedures will be appropriately utilized in the execution of this project. The management principles as presented in DOE Order 430.1, "Life Cycle Asset Management," will be appropriately utilized, in a graded approach, per the guidance of that order. 


\section{HNF-SD-SPJ-PMP-001 \\ Rev. 0}

\section{TABLE 10-1}

WHC-CM-6-2 "Project Management"

Procedures Not Being Utilized

\begin{tabular}{|c|c|c|}
\hline Procedure 1 & (1. & Reason for Non-Utilization \\
\hline PM-1 & Candidate Project Support Sheets & This project is specilic to Line Items, Major Projects, and MSA's \\
\hline PM-2 & Short Form Data Sheet & Programmatic (HQ) for Planning of Line Items, Major Projects, and MSA's \\
\hline PM-3 & Project Data Sheets & $\begin{array}{l}\text { Programmatic (HQ) for Annual Planning of Validated Line Items, Major Projects, } \\
\text { and MSA's }\end{array}$ \\
\hline$P M-4$ & Conceptual Design Plin & HQ Requirement for Conceptual Design Reports Planning \\
\hline PM-6 & Conceptual Design Ruport & $\begin{array}{l}\text { Used for Project Validation/Authorization of Line Items, Major Projects, and } \\
\text { MSA's }\end{array}$ \\
\hline PM-S & Request For Project Authorization & PA's no longer used under the PHMC \\
\hline PM-l 1 & Monthly and Quarterly Progress Rpts & Specilied Reporting Requirements for GPP's, Line Items and $A$ bove \\
\hline PM-12 & Project Document Mamagement & Specifies Document Requirements for GPP's, Line Items and Above \\
\hline PM-22 & Justification for Mission Need & HQ Document Required for Line-Items and Above \\
\hline PM-23 & Project Plan & HQ Requirement for Line-Items and Above with TEC $>\$ 10 \mathrm{M}$ \\
\hline
\end{tabular}




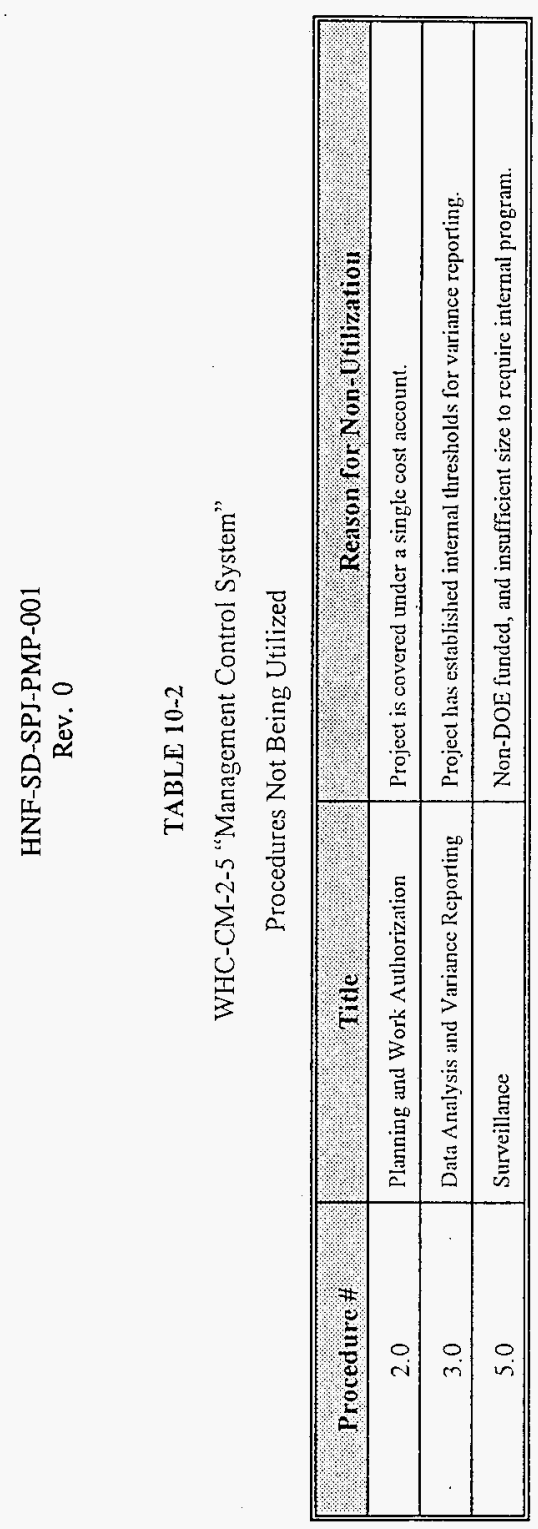


HNF-SD-SPJ-PMP-001

Rev. 0

\subsection{REPORTING REQUIREMENTS}

Project C-229 will be statused consistent with the normal project reporting practices used at the Hanford Site. The following reporting activities are scheduled:

- Bi-weekly Project Status Meeting, typically held every other Tuesday, this meeting is informal, and no written report is generated. Meeting minutes are documented as necessary.

- Monthly Budget and Cost Account Review; monthly report statising technical issues, schedule status, and budget status (including earned value analysis) will be reported at the cost account level using "percent complete" criteria based on a "remaining duration" method. Prepared and issued one week after accounting month close. Reports will be included in BWHC monthly management review meetings (MRMs).

- $\quad$ Earned value analysis will be performed on a monthly basis for all level 2 WBS activities, e.g. 1.0, 2.0, etc.) utilizing planned and actual costs for the lowest WBS level. Corrective action plans and mitigation activities will be defined for all activities wherein cumulative earned value analysis for ACWP (actual cost of work performed) indicates a negative variance of greater than $\$ 50 \mathrm{~K}$ and which exceeds $10 \%$ of the budget for the WBS cost account or a negative cumulative schedule variance of greater than $\$ 50 \mathrm{~K}$ and which exceeds $10 \%$ of the scope for a critical path element.

- Quarterly Senior Management Review when requested by senior management. 


\section{HNF-SD-SPJ-PMP-001}

Rev. 0

\subsection{CONFIGURATION MANAGEMENT/SYSTEMS ENGINEERING}

\subsection{CONFIGURATION MANAGEMENT}

Engineering documentation, calculations, design drawings, and specifications will be controlled and managed per standard Hanford Site practices (WHC-CM-6-1 and WHC-CM-6-2) Modifications to the 324 Building will not be necessary to accomplish this project.

The new storage site design and construction documentation will be controlled and managed per normal Hanford site configuration management procedures (WHC-CM-6-1 and WHC-CM-6-2); appropriate drawings will be as-built at the completion of construction and acceptance activities.

The waste storage cask drawings and associated specifications and inspection reports will be placed into the configuration management system after placement of waste containing casks at the interim storage site. Project documentation will be maintained in a project file for review and audit purposes. Appropriate project documentation, e.g., this PMP, will be controlled through normal Hanford documentation control processes (WHC-CM-6-1 and WHC-CM-6-2). A project specific configuration management plan (CMP) is not warranted for this project.

\subsection{SYSTEMS ENGINEERING}

The scope of this project does not warrant the preparation of a project specific systems engineering management plan (SEMP). Systems engineering concepts will be employed in the definition of interfaces between WBS elements. 
Rev. 0

\subsection{CHANGE CONTROL}

The project will utilize the standard Baseline Change Control Process, as defined in WHC-CM-2-5, "Management Control System." This project will utilize the BWHC change control board for change control actions.

Level II change requests can be approved by the BWHC change control board and the Project Manager.

All Level I change requests will be approved by the change control board, the project manager, and the Fluor Daniel Hanford Project Director and then transmitted to the RL Project Manager for approval.

Threshold limits are as defined in WHC-CM-2-5. 


\section{HNF-SD-SPJ-PMP-001}

Rev. 0

\subsection{READINESS DETERMINATION PLAN}

A readiness determination for all activities will be performed prior to start of load out of sources. The readiness determination will be performed per the guidance provided by WHC-CM1-5, "Standard Operating Practices", DOE Order 5480.31, "Startup and Restart of Nuclear Facilities", and RLID 5480.31, "Startup and Restart of Facilitates Operational Readiness Review and Readiness Assessment". Although this Order 5480.31 has been canceled, it is referenced in the RLID for readiness assessments.

Project staff have reviewed the project activities against the criteria of DOE Order 5480.31 and have made the determination that Project $\mathrm{C}-229$ does not constitute startup of a new facility or a significant modification to the CWC or the 324 Building. The activities associated with loading the canisters into the transportation/storage casks, transporting the casks to the ISA, and placing the casks in the ISA do not present a credible risk of radionuclide release. The stable form of the waste (vitrified sources) and the strength and durability of the packaging preclude credible release scenarios for the loaded casks. Based on this assessment, the FDH Facility Stabilization Project Director will act as the approval authority for initiation of Project C-229 waste transfers.

Each subcontractor responsible for completion of an activity within the scope of the project will prepare a checklist to address all of the applicable requirements within existing DOE Orders, DOE regulatory guides, and federal, state, and local regulations. Each subcontractor will be responsible for the resolution of any issues identified during the completion of the checklists. All issues will be resolved by the subcontractors prior to transmittal of approved checklists to the BWHC Project Manager for Project C-229. 


\section{HNF-SD-SPJ-PMP-001}

Rev. 0

The BWHC Project Manager will collect all of the approved checklists from the subcontractors responsible for Project C-229 activities. After reviewing the checklists to ensure their completion, the BWHC Project Manager will transmit the approved checklists and a request for approval to initiate waste transfers to the FDH Facility Stabilization Project director for approval.

Upon review of the completed checklists and concurrence that all necessary activities have been accomplished, the FDH Director will provide written approval to initiate source transfers to the BWHC Project Manager. The BWHC Project Manager will provide periodic status reports on readiness determination activities to the RL Transition Program Project Manager. 


\section{HNF-SD-SPJ-PMP-001}

Rev. 0

\subsection{PROJECT ORGANIZATION}

The project has been assigned to Transition Projects Division (TPD), Richland Operations Office (RL) for oversight of project execution. TPD/RL has assigned this project to Fluor Daniel Hanford (FDH). Day-to-day project management has been assigned to BWHC by FDH. In addition to BWHC staff, personnel participating in the project's tasks include those from the following Hanford Organizations:

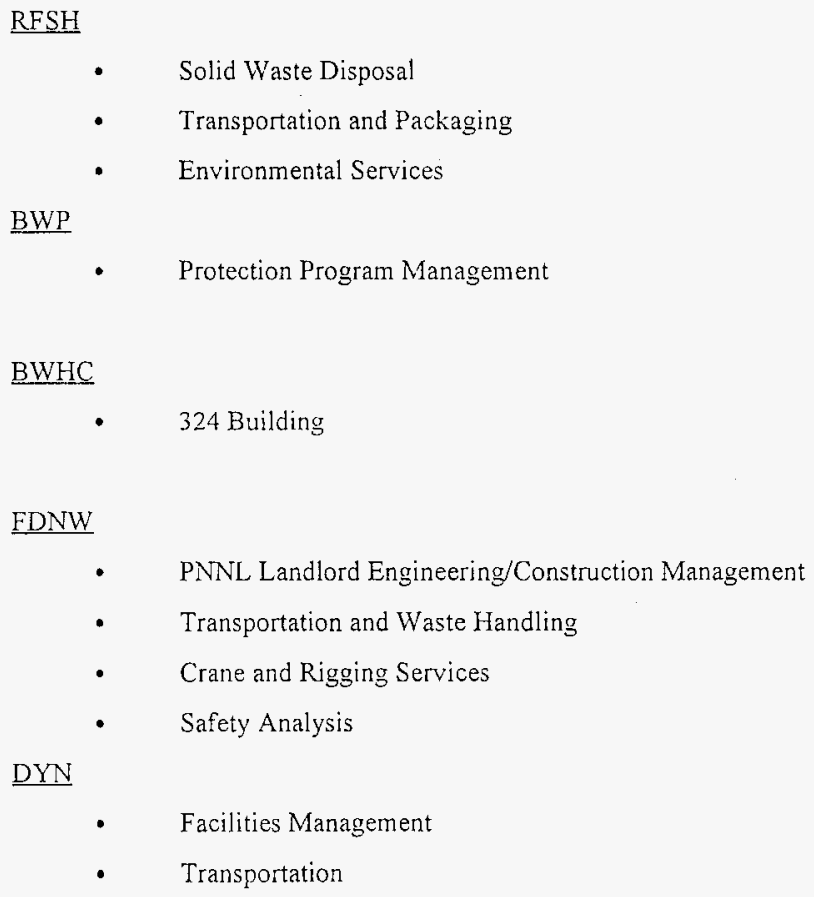


All design/construction activities will be performed under the technical oversight of appropriately assigned design authorities. A design authority will be assigned to support the project from Solid Waste (SW). It will be the responsibility of that design authority to review and approve all drawings and specifications associated with the future interim storage site.

Figure 15-1 presents the overlying project organization. Table 15-1 presents the responsibility assignment matrix (RAM) for the project. The RAM identifies organizational responsibility/authority for the execution of the various WBS elements. Work activities are prenegotiated, loaded into the financial data system, and authorized through the project manager. Table 15-2 presents the anticipated key documents for the project and the assigned approval requirements for these key documents. 
HNF-SD-SPJ-PMP-001

Rev. 0

Figure 15.1 - Project Organization

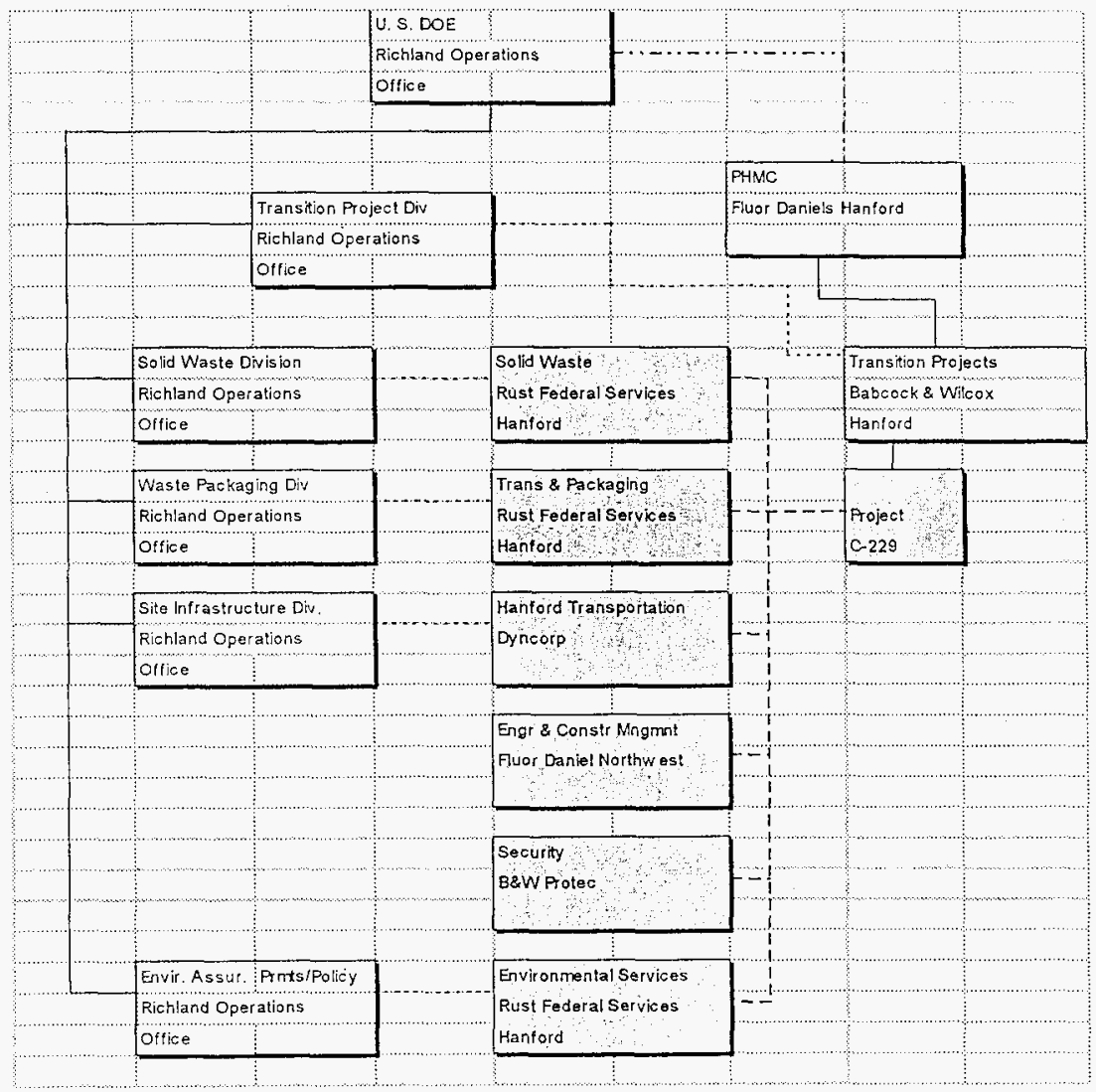


HNF-SD-SPJ-PMP-001

Rev. 0

Table 15-1

RESPONSIBILITY ASSIGNMENT MATRIX

\begin{tabular}{|c|c|c|c|c|c|}
\hline WBS & WBSTMTLE & Organigationipor & Dite & status: & Conninats \\
\hline 1.00 & Project Management & $\begin{array}{l}\text { BWHC } \\
\text { I.L. Metcalf }\end{array}$ & & & \\
\hline 1.10 & Project Management & $\begin{array}{l}\text { BWHC } \\
\text { I.L. Mctcalf }\end{array}$ & & & \\
\hline 1.20 & Project Controls & $\begin{array}{l}\text { BWHC } \\
\text { J. LeMarr }\end{array}$ & & & \\
\hline 1.30 & NEPA/Site Permits & $\begin{array}{l}\text { RFS } \\
\text { J.G. Granger }\end{array}$ & & & \\
\hline 1.40 & Quality Assurance & $\begin{array}{l}\text { FDNW } \\
\text { T.Z. (King) Anderson } \\
\text { BWHC } \\
\text { J.M. Tanke }\end{array}$ & & & \\
\hline 1.50 & Readiness Determination & $\begin{array}{l}\text { DynCorp } \\
\text { M.J. Brown }\end{array}$ & & & \\
\hline 1.60 & Path Fonvard & $\begin{array}{l}\text { BWHIC } \\
\text { I.L. Metcill }\end{array}$ & & & \\
\hline 2.00 & A-Cell Operations & $\begin{array}{l}\text { BWHIC } \\
\text { S.D. Halstead }\end{array}$ & & & \\
\hline 2.10 & $\begin{array}{l}\text { A-Cell } \\
\text { Surveillance/Maintenance }\end{array}$ & $\begin{array}{l}\text { BWHC } \\
\text { S.D. Halstead }\end{array}$ & & & \\
\hline
\end{tabular}


HNF-SD-SPJ-PMP-001

Rev. 0

\begin{tabular}{|c|c|c|c|c|c|}
\hline 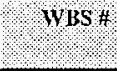 & (2. & Organibationlsos & Dato & strifus & Conninents \\
\hline 2.20 & $\begin{array}{l}\text { A-Cell Pre-Transfer } \\
\text { Preparation }\end{array}$ & $\begin{array}{l}\text { BWHIC } \\
\text { S.D. Halstead }\end{array}$ & & & \\
\hline 2.30 & Source La:d-Out Activities & $\begin{array}{l}\text { BWHC } \\
\text { S.D. Halstead }\end{array}$ & & & \\
\hline 2.40 & $\begin{array}{l}\text { Post Transfer } \\
\text { Decontamination and } \\
\text { Decommissioning }\end{array}$ & $\begin{array}{l}\text { BWHC } \\
\text { S.D. Hillstead }\end{array}$ & & & \\
\hline 3.00 & $\begin{array}{l}\text { CaskTransportation } \\
\text { Activitics }\end{array}$ & $\begin{array}{l}\text { FDNW } \\
\text { D.M. LaRue }\end{array}$ & & & \\
\hline 3.10 & $\begin{array}{l}\text { Shipping/Storage Cask } \\
\text { Acquisition }\end{array}$ & $\begin{array}{l}\text { FDNW } \\
\text { E.F. Kochling }\end{array}$ & & & \\
\hline 3.20 & SARP Preparation & $\begin{array}{l}\text { RFS } \\
\text { E.P. Clements (CASTOR) } \\
\text { M.E. Burnside (GFS-12) }\end{array}$ & & & \\
\hline 3.30 & Transfer Operations & $\begin{array}{l}\text { DynCorp } \\
\text { F.P. Clements }\end{array}$ & & & \\
\hline 4.00 & Site Preparation/Storage & $\begin{array}{l}\text { RFS } \\
\text { R.R. Ames }\end{array}$ & & & \\
\hline 4.10 & $\begin{array}{l}\text { Consequence } \\
\text { Analysis/Vulnerability } \\
\text { Assessment }\end{array}$ & $\begin{array}{l}\text { BWP } \\
\text { C.J. (Skip) Udell }\end{array}$ & & & COMPLETED \\
\hline 4.20 & $\begin{array}{l}\text { SW SAR Modification and } \\
\text { USQ Disposition }\end{array}$ & $\begin{array}{l}\text { RFS (TDNW) } \\
\text { R.R. Ames (D. Porten) }\end{array}$ & & & \\
\hline
\end{tabular}


HNF-SD-SPJ-PMP-001

Rev. 0

\begin{tabular}{|c|c|c|c|c|c|}
\hline 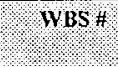 & ४WBSTII LE, & Organizationipos & onte & Stritus & Comnents \\
\hline 4.30 & $\begin{array}{l}\text { Site Selection/Functional } \\
\text { Design Criteria }\end{array}$ & $\begin{array}{l}\text { FDNW } \\
\text { C.M. Consclman/ } \\
\text { E.G. Erpenbeck }\end{array}$ & & & \\
\hline 4.40 & $\begin{array}{l}\text { Waste Acceptance } \\
\text { Documentation }\end{array}$ & $\begin{array}{l}\text { DynCorp } \\
\text { M.J. Brown }\end{array}$ & & & \\
\hline 4.50 & $\begin{array}{l}\text { Storige Site } \\
\text { Design/Construction }\end{array}$ & $\begin{array}{l}\text { FDNW } \\
\text { C.M. ConsclmanvE.G. } \\
\text { Erpenbeck }\end{array}$ & & & \\
\hline
\end{tabular}

${ }^{1}$ Randall R. Ames is the assigned design authority for Solid Waste activities. 
HNF-SD-SPJ-PMP-001

Rev. 0

Table 15-2

KEY DOCUMENTS/APPROVAL REQUIREMENTS

\begin{tabular}{|c|c|c|c|c|c|c|c|c|}
\hline DOCUMENT & $\begin{array}{c}\text { BWHC } \\
\text { PM }\end{array}$ & $\begin{array}{l}324 \text { Bldg } \\
\text { Mngment }\end{array}$ & $\begin{array}{l}\mathrm{FDH} \\
\mathrm{PM}\end{array}$ & $\mathrm{RL}^{2}$ & $\begin{array}{l}\text { RFS SW } \\
\text { Des Auth }\end{array}$ & $\begin{array}{l}\text { RFs SW } \\
\text { Mngtruit }\end{array}$ & $\begin{array}{l}\text { RFS TT } \\
\text { Des Auth }\end{array}$ & $\begin{array}{l}\text { RFS TrP } \\
\text { Mngmin }\end{array}$ \\
\hline C-229 PMP & $x$ & $\mathrm{x}$ & $x$ & $\mathrm{x}$ & & & & \\
\hline FDC (Stornge Site) & $x$ & & & $x$ & $x$ & $\mathrm{x}$ & & \\
\hline Project Schedule & $x$ & $\mathrm{R} / \mathrm{C}$ & & & $R^{\prime} C$ & $\mathrm{RC}$ & $\mathrm{R} / \mathrm{C}$ & $\mathrm{R} / \mathrm{C}$ \\
\hline CASTOR GSF PDC & $\mathrm{R} / \mathrm{C}$ & & & $\mathrm{x}$ & & & $\mathrm{x}$ & $\mathrm{x}$ \\
\hline GNS-12 Cusk PDC & $\mathrm{R} / \mathrm{C}$ & & & $\mathrm{X}$ & & & $\mathrm{x}$ & $\mathrm{x}$ \\
\hline SARP CASTOR SARP & $\mathrm{R} / \mathrm{C}$ & & & $\mathrm{x}$ & & & $x$ & $\mathrm{x}$ \\
\hline GNS-12 SARP & $\mathrm{RC}$ & & & $x$ & & & $\mathrm{x}$ & $x$ \\
\hline SW SAR ECN/USQD & $\mathrm{R} / \mathrm{C}$ & & & $\mathrm{x}$ & $x$ & $\mathrm{X}$ & & \\
\hline Readiness Delermin 324 Bldg. & $x$ & $x$ & $\mathrm{x}$ & & & & & \\
\hline Readiness Detcrmin CWC Site & $x$ & & $\mathrm{x}$ & & $x$ & $\mathrm{x}$ & & \\
\hline Readiness Determin T $n$ & $x$ & & $\mathrm{x}$ & & & & $\mathrm{X}$ & $\mathrm{x}$ \\
\hline Environmental Assannl & $x$ & & & $x$ & $\mathrm{x}$ & $\mathrm{x}$ & & \\
\hline Read. Determin Plar & $x$ & $x$ & $\mathrm{x}$ & $\mathrm{x}$ & $\mathrm{R} / \mathrm{C}$ & $\mathrm{x}$ & $\mathrm{R} / \mathrm{C}$ & $x$ \\
\hline
\end{tabular}

$\mathrm{X}$ - Approval

R/C - Review Comment

'The RL-TPD P'roject Manager is responsible for determining and obtaining the appropriate RL signature. 